\title{
THE EFFECTS OF THE ADDUCTION OF EFFERVESCENT POWDER OF BASTARD CEDAR LEAF (GUAZUMA ULMIFOLIA LAMK.) EXTRACT TOWARD WEIGHT REDUCTION OF MALE MICE
}

\author{
SUMAIYAH ${ }^{1 *}$, RIZKY TRIANDINI ${ }^{2}$, AMINAH DALIMUNTHE ${ }^{2}$ \\ ${ }^{1}$ Department of Pharmaceutical Technology, Faculty of Pharmacy, University of Sumatera Utara, Medan, Indonesia, ${ }^{2}$ Department of \\ Pharmacology, Faculty of Pharmacy, University of Sumatera Utara, Medan, Indonesia. Email: sumaiyah@usu.ac.id
}

Received: 07 March 2018, Revised and Accepted: 25 March 2018

\section{ABSTRACT}

Objective: The objective of this study was to discover the effect of the adduction of Bastard cedar leaf extract that was formulated in the form of effervescent powder toward weight loss.

Methods: The study design was an experimental study with pretest-posttest one group control design. The sample was divided into 3 treatment groups which were dosage $1 \mathrm{~g} / \mathrm{kg}$ body weight (BW), $2 \mathrm{~g} / \mathrm{kg} \mathrm{BW}$, and $3 \mathrm{~g} / \mathrm{kg}$ BW of Bastard cedar leaf effervescent powder and one control group. The research was conducted for 28 days.

Result: The result of the research exhibited the $1^{\text {st }}$ day of the adduction of Bastard cedar leaf effervescent powder that the dosage 3 g/Kg BW contributed to the largest reduction compared with the others. On the last day of adduction, dosage $1 \mathrm{~g} / \mathrm{Kg}$ BW contributed almost the similar weight reduction effect to the mouse with the dosage $3 \mathrm{~g} / \mathrm{Kg} \mathrm{BW}$; however, when both were compared, the dosage $3 \mathrm{~g} / \mathrm{Kg}$ BW remained giving the most significant effect $(\mathrm{p}<0.05)$.

Conclusion: The adduction of bastard cedar leaf effervescent powder could reduce the weight of the mouse in all dosage treatment which was dosage $1 \mathrm{~g} / \mathrm{Kg} \mathrm{BW}, 2 \mathrm{~g} / \mathrm{Kg} \mathrm{BW}$, and $3 \mathrm{~g} / \mathrm{Kg} \mathrm{BW}$.

Keywords: Effervescent powder, Guazuma ulmifolia Lamk., Extract, Weight reduction.

(C) 2018 The Authors. Published by Innovare Academic Sciences Pvt Ltd. This is an open access article under the CC BY license (http://creativecommons. org/licenses/by/4. 0/) DOI: http://dx.doi.org/10.22159/ajpcr.2018.v11s1.26604

\section{INTRODUCTION}

Bastard cedar leaf (Guazuma ulmifolia Lamk.) is a tree plant with height of $10 \mathrm{~m}-20 \mathrm{~m}$. This plant is slim-branched dicotyle plant. Bastard cedar is renowned as medicinal plant that has the property to reduce weight. The bean can be utilized as the medicine for stomachache and bloating. The fruit can be used as medicine for cough. The stem bark of the plant can cure swollen on foot. The plant can also function to treat influenza, dysentery, wound, and fracture. The leaf can be used as antihypercholesterolemic, antidiabetic, and antiobesity. The leaf is the part of the plant that is commonly used as the ingredient for slimming potion [1-3].

The Bastard cedar leaf is expected to degrade the fat with the chemical contents of alkaloids, flavonoids, saponins, tannins, mucilage, carotenoids, phenolic acids, and resins. The alkaloid content of the leaf has similar chemical structure to orlistat, synthetic medicine that can suppress appetite by inhibiting the performance of lipase enzyme so that the absorption of fat is reduced [4].

Obesity is the clinical condition that could be a public health problem. This happens due to the faulty shifting of people's lifestyle and becomes risk factors of several ailments, such as hypertension, diabetes mellitus Type 2, stroke, and osteoarthritis. Obesity occurs due to the imbalance of energy for a long time, and the total energy expenditure (energy expenditure) is smaller than energy intake (energy input), resulting in the accumulation of energy reserves stored in subcutaneous and visceral fat [5].

Bastard cedar leaf effect on weight loss was ever studied toward white mice, using ethanol extract of Bastard cedar leaf. The results showed a statistically significant difference in weight loss in rats between the treated group and the controlled group [4].
As the Bastard cedar leaf was never produced in the form of effervescent powder, researchers are interested to make effervescent powder from Bastard cedar leaf extract as a weight loss ingredient. In this research, Bastard cedar leaf was processed to be a form of effervescent powder with concentration of acid source using Hydroxypropyl methyl cellulose binder. The acid source used was the combination of citric acid and tartaric acid. To produce an effervescent reaction, it requires 3 citric acid molecules and 2 sodium bicarbonate molecules to neutralize one tartaric acid molecule [6].

Based on the above explanation, therefore, the author is interested to do research on the effect of effervescent powder from Bastard cedar leaf (G. ulmifolia Lamk.) toward weight loss of mice, which can be used as alternative therapy to lose weight and as reference for the following research to support the development of knowledge.

\section{MATERIALS AND METHODS}

\section{Animal grouping}

The population of the research was the male mice aged 2-3 months with \pm 25 g weight and healthy characterized by active movement.

There were 4 groups that were used in this study. The number of samples in each group were 6 mice. The animals were divided into 3 treated groups and 1 controlled group, with the following details:

1. Group A was given dosage $1 \mathrm{~g} / \mathrm{Kg} \mathrm{BW}$ of Bastard cedar leaf extract.

2. Group B was given dosage $2 \mathrm{~g} / \mathrm{Kg}$ BW of Bastard cedar leaf extract.

3. Group C was given dosage $3 \mathrm{~g} / \mathrm{Kg} \mathrm{BW}$ of Bastard cedar leaf extract.

4. Group D was given distilled water (control)

\section{Materials}

The materials used were Bastard cedar leaf extract, 96\% ethanol (E-Merck), lactose, citric acid, tartaric acid, sodium carbonate, Mg stearate, aspartame, and hydroxypropyl methyl cellulose. All other chemicals used were of analytical grade. 


\section{Methods}

\section{Preparation of dry extract}

The viscous Bastard cedar leaf extract was dried with lactose at a ratio of 1:8 until the powdered extract was formed, then sieved with a 40 mesh sieve, and then dried in dryer cup for $\pm 18 \mathrm{~h}$

\section{Formula of effervescent powder}

Effervescent powder was made by wet granulation method. The composition of Na bicarbonate with citric acid and tartaric acid based on the balance of acid-base reaction, in which to neutralize 1 citric acid molecule, 3 molecules of $\mathrm{Na}$ bicarbonate are required, and to neutralize 1 molecule of tartaric acid, 2 molecules of Na Bicarbonate are required [6]

The effervescent powder formulation used in this study can be seen in Table 1.

\section{Phases in formulation of Bastard cedar leaves effervescent powder} Base phase

Half of the total dried extract and lactose crushed in mortar until it was homogeneous. Natrium bicarbonate was added, half aspartame and half HPMC mixed in mortar until it was homogeneous, 96\% ethanol was added to form a compact mass and sifted through a 14 mesh sieve and dried in an oven at $40^{\circ} \mathrm{C}$. The granules obtained was sieved with a 16 mesh sieve to get the smaller granules [7].

\section{Acid phase}

Half of the total dried extract and half of the total lactose were crushed in mortar until it was homogeneous. Citric acid was added little by little while being crushed homogeneous and tartaric acid was added, and aspartame and half parts of HMPC crushed until it was homogeneous. $96 \%$ ethanol was added to form a compact mass and sifted through a sieve of 14 mesh and dried in an oven at $40^{\circ} \mathrm{C}$. Then the granules obtained was sifted through a sieve 16 mesh to get the smaller granules [7]

\section{Outer phase of effervescent powder formulation of Bastard cedar} leaves

The outer phase comprises of Mg stearate as the lubricant which was mixed in parts of acid and base that have been dried and ready to be compressed.

\section{Induction of obesity}

The induction of obesity was held using monosodium glutamate (MSG). Two grams of MSG was dissolved in $10 \mathrm{ml}$ of distilled water, and then $1 \%$ of the BW solution was injected subcutaneously for each mouse and was performed for 2 consecutive weeks to increase the weight of the mice.

\section{Dosage determination}

The effective dose of Bastard cedar leaf extract was 1g/kg BW. The dose of Bastard cedar leaf extract for mice was 1, 2, and $3 \mathrm{~g} / \mathrm{kg} \mathrm{BW}$ [8].

The effervescent powder of Bastard cedar leaves was done after 14 days of obesity induction, and the mice were given effervescent doses of

Table 1: Effervescent powder formula of Bastard cedar leaves [7]

\begin{tabular}{ll}
\hline Material (mg) & F1 (mg) \\
\hline Dry extract of Bastard cedar leaf & 500 \\
Citric acid & 150 \\
Tartaric acid & 250 \\
Natrium bicarbonate & 460 \\
Aspartame & 40 \\
HPMC & 60 \\
Mg stearate & 30 \\
Lactose & 510 \\
Total & 2000 \\
\hline HPMC: Hydroxypropylmethylcellulose &
\end{tabular}

Bastard cedar leaves with prescribed doses and orally administered once every day for 14 days. Controlled group was given distilled water orally once every day for 14 days.

Preparation of Bastard cedar leaves effervescent powder solution Preparation of effervescent powder of Bastard cedar leaves using the dose $1 \mathrm{~g}, 2 \mathrm{~g}$, and $3 \mathrm{~g} / \mathrm{kg}$ body weight. Effervescent powder of Bastard cedar leaves was weighed as much as $1250 \mathrm{mg}$, and the powder was put into glass beaker and added with distilled water up to $12.5 \mathrm{ml}$.

\section{The adduction of effervescent bastard cedar leaf powder}

The adduction of effervescent powder of Bastard cedar leaves was done daily for 2 weeks according to the dose of the treatment group that had been determined. The measurement of BW was conducted once in 2 days during the treatment to observe the transformation of BW.

\section{Data analysis}

The observation result was analyzed statistically with t-test and oneway ANOVA method (variance analysis) that was continued with Duncan test with significance rate of $95 \%$. This statistical analysis used the Statistical Product and Service Solution program version 19.

\section{RESULTS AND DISCUSSION}

The BW of The Mice (Mus musculus $L$ ) after the adduction of MSG The adduction of MSG with dosage of $2 \mathrm{~g}$ during 14 days towards male mice's BW resulted numbers is shown in Fig. 1 and Table 2.

To determine if the BW of the mice increased significantly, t-test was conducted. It was held on 4 groups of mouse after MSG was given toward average mouse's body weight and the result showed p-value as much as 0.000 that was less than significance value of 0.05 . Thus, monosodium glutamate significantly contributes to the increased of weight in male mice therefore cause obesity to the mice. The average weight of mouse in 4 treatment groups was $\pm 25 \mathrm{~g}$, and after the adduction of MSG, the average weight for the 4 treatment groups became $\pm 31 \mathrm{~g}$.

Mouse BW after the adduction of effervescent powder of bastard cedar leaves

The effect of effervescent powder of Bastard cedar leaves toward male mouse's BW is shown in Fig. 2 and Table 3.

The variance analysis test from the data on day 14 showed the value of 0.539 ( $p>0.05)$. This exhibits that there was no difference in average of mouse BW loss before the adduction of effervescent powder of Bastard cedar leaves toward male mouse.

The variance analysis test from the data on day 16 showed the value of 0.011 , on day 18 showed the value of 0.003 , and on day 20, 22, 24,26 , and 28 showed the value of $0.000(p<0.05)$. These showed that there was difference of average mouse's BW loss after adduction of effervescent powder of Bastard cedar leaves. The continued Duncan test showed that among the 3 treatments, dosage $3 \mathrm{~g} / \mathrm{Kg}$ BW contributed to the most significant effect compared to 2 other dosages.

Based on the t-test, it can be concluded that the adduction of the effervescent powder of Bastard cedar leaves could reduce the weight of the obesed male mouse.

The result of t-test that was conducted on the last day (day 28) to the $1^{\text {st }}$ day (day 0 ) to observe if the period of 14 days of adduction of the effervescent powder of Bastard cedar leaves to reduce BW of male mouse was $0.014(\mathrm{p}<0.05)$. This meant that there was a sufficient significance between $1^{\text {st }}$ day and last day, and thus, it can be concluded that 14 day of adduction of the effervescent powder of Bastard cedar leaves was sufficient to reduce the BW of the mouse. 
Table 2: Mice's BW data after adduction of $2 \mathrm{~g}$ MSG

\begin{tabular}{|c|c|c|c|c|c|c|c|c|c|c|}
\hline \multirow[t]{3}{*}{$\mathbf{T}$} & \multicolumn{10}{|c|}{ Average body weight and the index (g) } \\
\hline & \multicolumn{2}{|c|}{ Day 1} & \multicolumn{2}{|c|}{ Day 4} & \multicolumn{2}{|c|}{ Day 7} & \multicolumn{2}{|c|}{ Day 10} & \multicolumn{2}{|c|}{ Day 14} \\
\hline & BW & BWI & BW & BWI & BW & BWI & BW & BWI & BW & BWI \\
\hline T1 & 25.9 & 103.1 & 26.6 & 106.1 & 28.5 & 113.8 & 29.7 & 118.8 & 31.6 & 126.1 \\
\hline $\mathrm{T} 2$ & 24.8 & 100.2 & 26.5 & 107.2 & 27.8 & 112.6 & 29.6 & 119.9 & 31.8 & 128.8 \\
\hline T3 & 25.7 & 100.6 & 27.2 & 106.8 & 29.1 & 114.0 & 30.9 & 121.2 & 32.9 & 128.8 \\
\hline $\mathrm{T} 4$ & 24.6 & 101.2 & 26.2 & 107.1 & 27.3 & 112.4 & 29.3 & 120.9 & 31.3 & 128.5 \\
\hline
\end{tabular}

T: Treatment, BW: Body WEIGHT, BWI: Body weight index, T1: EPBCL with dose $1 \mathrm{~g} / \mathrm{kg} \mathrm{BW,} \mathrm{T2:} \mathrm{EPBCL} \mathrm{with} \mathrm{dose} 2$ g/kg BW, T3: EPBCL with dose 3 g/kg BW,

T4: Distilled water (control). MSG: Monosodium glutamate

Table 3: Average mouse BW data after adduction of effervescent powder of Bastard cedar leaves during day 14 to day 28

\begin{tabular}{|c|c|c|c|c|c|c|c|c|c|c|c|c|c|c|c|c|}
\hline \multirow[t]{3}{*}{$\mathbf{T}$} & \multicolumn{16}{|c|}{ Average body weight (g) } \\
\hline & \multicolumn{2}{|c|}{ Day 14} & \multicolumn{2}{|c|}{ Day 16} & \multicolumn{2}{|c|}{ Day 18} & \multicolumn{2}{|c|}{ Day 20} & \multicolumn{2}{|c|}{ Day 22} & \multicolumn{2}{|c|}{ Day 24} & \multicolumn{2}{|c|}{ Day 26} & \multicolumn{2}{|c|}{ Day 28} \\
\hline & BW & BWI & BW & BWI & BW & BWI & BW & BWI & BW & BWI & BW & BWI & BW & BWI & BW & BWI \\
\hline $\mathrm{T} 1$ & 31.6 & 126.1 & 30.8 & 97.2 & 29.7 & 93.8 & 30.3 & 95.8 & 29.3 & 92.6 & 27.8 & 88.0 & 28.2 & 89.3 & 27.2 & 86.2 \\
\hline $\mathrm{T} 2$ & 31.8 & 128.8 & 29.7 & 93.0 & 31.3 & 98.5 & 30.5 & 96.1 & 31.1 & 97.7 & 30.7 & 96.6 & 30.5 & 96.2 & 29.9 & 94.2 \\
\hline T3 & 32.9 & 128.8 & 30.3 & 91.8 & 28.6 & 86.9 & 30.5 & 92.8 & 30.2 & 91.7 & 28.8 & 87.6 & 27.7 & 84.4 & 27.9 & 84.9 \\
\hline $\mathrm{T} 4$ & 31.3 & 128.5 & 31.5 & 100.7 & 32.9 & 105.2 & 32.9 & 105.3 & 32.7 & 104.7 & 33.8 & 108.1 & 34.3 & 109.8 & 34.9 & 111.6 \\
\hline
\end{tabular}

T: Treatment, BW: Body weight, BWI: Body weight index, T1: EPBCL with dose 1 g/kg BW, T2: EPBCL with dose 2 g/kg BW, T3: EPBCL with dose 3 g/kg BW, T4: Distilled water (control)

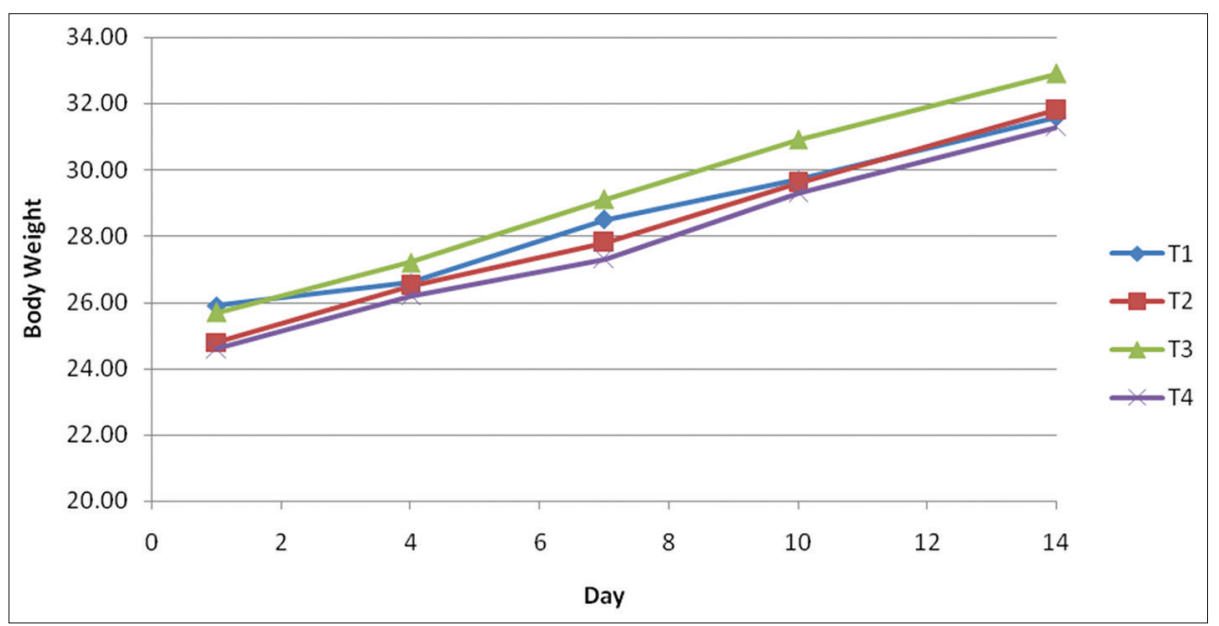

Fig. 1:Graph of mice's body weight after adduction of $2 \mathrm{~g}$ monosodium glutamate

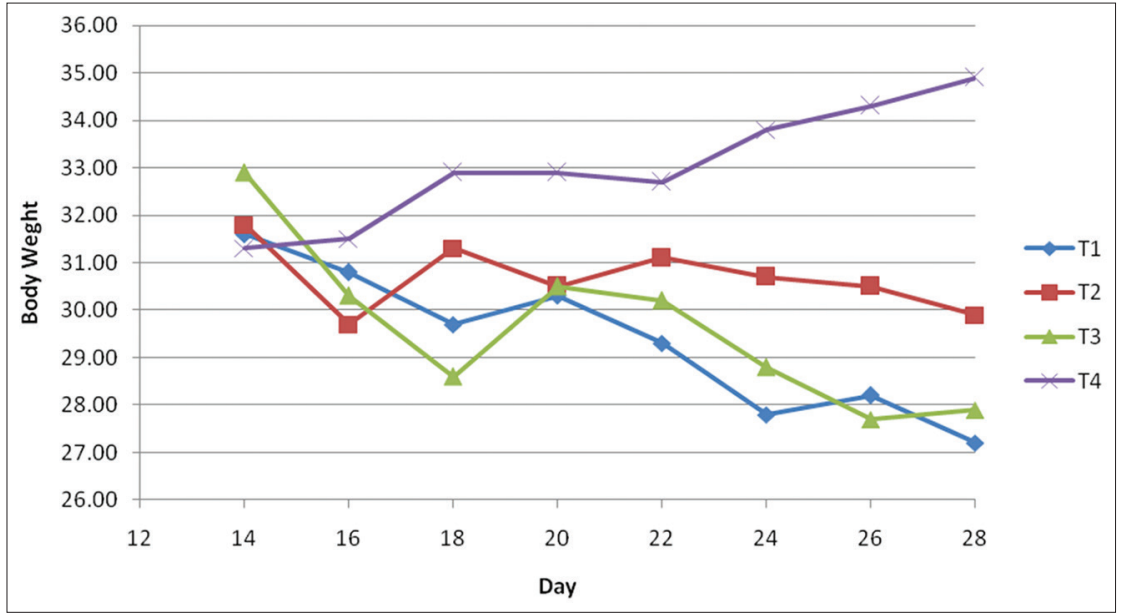

Fig. 2: Graph of average mouse body weight after adduction of effervescent powder of bastard cedar leaves during day 14 to day 28 
There was a difference of weight loss of male mice between the treated group and the controlled group, the treatment with $1 \mathrm{~g} / \mathrm{Kg} \mathrm{BW}$ dose almost gave the same effect as the $3 \mathrm{~g} / \mathrm{Kg} \mathrm{B}$ dose, but when compared to the other two doses, the $3 \mathrm{~g} / \mathrm{Kg} \mathrm{B}$ dose gave the most significant impact to weight loss.

Mice weight loss in treatment group was suspected because of the content of bioactive compound in effervescent powder of Bastard cedar leaf. The content of bioactive compound of effervescent powder of Bastard cedar leaves that allegedly give effect to lose weight is tannin, mucilage, and alkaloid. Tannin compounds have the effect of precipitating proteins present in the small intestine surface because it is easy to bind to proteins, thereby reducing the absorption of food, and thus, the process of obesity can be inhibited. Mucilage compound contained in Bastard cedar leaf is polysaccharide in the form of mucus and characterized as a lubricant so that in the presence of mucilage, the absorption of food in the intestine can be reduced [9]

In addition to the influence of tannin and mucilage compounds, the weight loss of mice can also be caused by the alkaloid content in the effervescent powder. The alkaloid compound in effervescent powder of Bastard cedar leaves allegedly can inhibit pancreatic lipase enzyme activity [10]. Lipase enzyme is the enzyme that hydrolyzes the fatty ester bonds into alcohol and fatty acids. The activity of lipase enzyme will increase the absorption of fatty acid. Conversely, if lipase enzyme activity is inhibited, then what happens is that absorption of fat is reduced so that much fat is wasted through the feces. The increase of the BW of the mouse on the controlled group was suspected because of physiology of the mouse that allows mouse to be stressed during straining. Stress could cause the blood glucose rate decreased which caused higher consuming activity of mouse to obtain sufficient glucose supply in the body [11].

\section{CONCLUSION}

Effervescent powder of Bastard cedar leaf gives weight loss effect to male mice in all three doses, i.e., $1 \mathrm{~g}, 2 \mathrm{~g}$, and $3 \mathrm{~g} / \mathrm{Kg} \mathrm{BW}$.

\section{ACKNOWLEDGMENT}

The authors are grateful for the Faculty of Pharmacy University of Sumatera Utara that has provided the Bastard cedar leaves and facilitated this research.

\section{REFERENCES}

1. Suharmiati MH. Benefits of Jati Belanda as Body Slimming and Anticholesterol. Depok: Agromedia Pustaka; 2003. p. 22-3.

2. Sukandar EY, Nurdewi, Elfahmi. Antihypercholesterolemic effect of combination of Guazuma ulmifolia Lamk. leaves and Curcuma xanthorrhiza Roxb. rhizomed extract in wistar rats. Int J Pharmacol 2012;8:277-82.

3. Adnyana IK, Yulinah E, Yuliet, Kurniati NF. Antidiabetic activity of aqueous leaf extracts of Guazuma ulmifolia Lamk., ethanolic extracts of Curcuma xanthorrhiza and their combinations in alloxan-induced diabetic mice. Res J Med Plants 2013;7:158-64.

4. Rahardjo S, Ngatijan, Pramono S. Pancreatic lipase activity Rattus novergicus due to provision of ethanol extract dutch teak leaves (Guazuma ulmifolia Lamk.). J Med Sci 2006;38:15-23

5. Mursito B. Traditional Herbs For Body Slimming. Jakarta: Penebar Swadaya; 2004. p. 58-60

6. Ansel HC. Introduction to Pharmaceutical Dosage Form. $4^{\text {th }}$ ed. Jakarta: UI Press; 1989.

7. Wati R. Effervesent Tablet Formulation from Jati Belanda Leaf Extract (Guazuma ulmifolia Lamk) with Variation and Amount of Acid. Essay. Medan: Universitas Sumatera Utara; 2016. p. 28-30.

8. Rahayu SY. Efficacy of Jati Belanda leaf on Lipid Concentration of Liver Mice Hiperlipidemia. Essay. Bogor: Department of Biochemistry FMIPA IPB; 2007. p. 11-2.

9. Widyati RM. The Effect of Jati Belanda Leaf Extract (Guazuma ulmifolia Lamk) on Weight Loss, Weight of Testis, and Number of Sperm Mice (Mus musculus L). Essay. Bandung: Universitas Pendidikan Indonesia; 2012. p. 57-92

10. Iswantini D, Silitonga RF, Martatilova E, Darusman CK. Zingiber cassumunar, Guazuma ulmifolia, and Murayya paniculata extracts as antiobesity: In vitro inhibitory effect on pancreatic lipase activity. Hayati J Biosci 2011;18:6-10.

11. Nugroho SA. Relationship between Stress Level on Blood Sugar Levels of Diabetes Mellitus Patients in Work Area of Sukoharjo I Sukoharjo District Health Center. Essay. Surakarta: Muhammadiyah University of Surakarta; 2010. p. 44. 